Britain and the United States, had 20-30 per cent of the people suffering from malnutritional diseases before the War. The near-famine conditions now faced by the world are nothing new, but shortages are affecting those who, by their advantageous economic position, had previously been virtually immune from even the fear of famine.

Britain imports the largest quantity of food of any country in the world-in some cases as much in normal times as two thirds of the total of a given commodity entering into the world trade. If exporters are no longer compelled by economic needs to sell the food they badly need themselves, then the position is indeed difficult for the importers. The world position has been aggravated by that greatest scourge ever known to man-soil erosion-and the irrational over-exploitation of forests, fisheries and grasslands. The plea is made for policies based on real knowledge and quantitative data rather than half-knowledge or guess-work.

\section{'Wellcome' Photographic Year Book}

THE well-known 'Wellcome' Exposure Calculator, Handbook and Diary, published by Burroughs Wellcome and Co., has appeared in a modified form as the 'Wellcome' Photographic Year Book. The contents are similar, and those who made use of the original publication before the War will remember that it consists essentially of a diary, a number of pages ruled for recording the essentials of photo. graphic exposures, a fund of useful photographic information, and a very useful exposure calculator. Used in conjunction with the illustrated examples of different types of subject, the calculator is one of the best of its kind. On the back of the exposure calculator, also in disk form, is a depth of field calculator with which the depth of field can be obtained for lenses of various apertures and focal lengths. The keen photographer will find the Year Book a valuable asset for the pocket.

\section{Frank B. Jewett Fellowships: Awards}

Tне American Telephone and Telegraph Company, which founded the Frank B. Jewett fellowships for research in the physical sciences three years ago to commemorate the retirement of its eminent vicepresident in charge of development and research, has announced seven awards for 1947-48. The purpose of the fellowships is to stimulate and assist research in the fundamental physical sciences, and particularly to provide the holders with opportunities for individual growth and development as creative scientific workers. The awards carry an annual stipend of 3,000 dollars to the holder and 1,500 dollars to the institution at which the recipient elects to do research. The awards are designedly post-doctorate, and only those who have recently received their doctorates or who are about to receive them are normally considered.

The awards for 1947-48 have been made to : (1) Dr. Martin G. Ettlinger (University of Texas and Harvard University), at present investigating the chemistry of cyclopropene and dicyclobutane derivatives at the California Institute of Technology as a Jewett Fellow for 1946-47; he intends to continue his present research studies. (2) Wallace D. Hayes (California Institute of Technology), who proposes to investigate problems of transonic and supersonic fluid flow. (3) Paul Olum (Harvard and Princeton Universities); he is to carry out research in algebraic topology. (4) Aadne Ore (University of Oslo), at present an F. E. Loomis Fellow at Yale University ; he will work on the theory of combinations of electrons and positrons. (5) Dr. Alfred Schild (University of Toronto and the Carnegie Institute of Technology); he will study relativistic field theories in quantum mechanics. (6) Dr. Robert L. Scott (Harvard and Princeton Universities), at present Jewett Fellow, engaged in research in chemistry at the University of California; he is to continue his studies of the thermodynamics of solutions. (7) Edwin H. Spanier (Universities of Minnesota and Michigan), at present a Rackham Predoctoral Fellow at the University of Michigan ; he will engage in research in the homotopy classification of continuous mappings.

\section{British Iron and Steel Research Association: Appointments}

Mr. R. H. MYers has been appointed head of the Steel Making Division of the British Iron and Steel Research Association and Dr. A. H. Leckie has been appointed deputy head. Mr. Myers studied under Profs. J. O. Arnold and A. MacWilliam at Sheffield, and, after a post-graduate course of one year, started his industrial career with the Midland Iron Company. Since 1930 he has been associated with research in the steel industry, as open-hearth officer to the Iron and Steel Industrial Research Council, in addition playing an active part in the Corrosion and Heterogeneity Committees set up jointly by the Research Council and the Iron and Steel Institute.

Dr. A. H. Leckie studied chemistry at University College, London, under Profs. F. G. Donnan and C. K. Ingold. After graduating, he was engaged in research for several years on molecular spectroseopy. In 1937 he joined the Technical Department of the British Iron and Steel Federation and was engaged on research on iron and steel works plant and prin. cipally on open-hearth furnaces. Dr. Leckie joined the British Iron and Steel Research Association, when that body took over the work of the Federation's Technical Department, and is in general charge of research work on furnace design and operation.

\section{Radiocommunication Convention}

THE Institution of Electrical Engineers is holding a Radiocommunication Convention during March 25-28, at which some seventy papers will be presented dealing particularly with war-time activities in this field and their resulting application to future peace-time development. The Convention will be opened on March 25 by Sir Stafford Cripps, President of the Board of Trade, after which Sir Stanley Angwin will give a lecture on "Telecommunications in War" On March 26 four meetings will be held dealing in turn with long-distance point-to-point communication, naval, military and aeronautical communication, and the special features of pulse modulation in communication systems. The subject of short distance communication will be dealt with during the following morning, while the afternoon and evening sessions of March 27 will be devoted to direction-finding and war-time broadcasting respectively. On the norming of March 28, Sir Edward Appleton will open the session on propagation with a paper entitled "The Investigation and Forecasting of Innospheric Conditions". The afternoon of the same day will be devoted to radio components, and in the evening, Sir Clifford Paterson will conclude with a review of the Convention and the future trends of development indicated by the papers and discussions. At an 